\title{
Association of Caspase-8 Genotypes With Bladder Cancer Risk
}

\author{
MENG CHEN ${ }^{1 *}$, YUEH-TING TSAI $^{2,3^{*}}$, WEN-SHIN CHANG ${ }^{3 *}$, LIANG-CHUN SHIH $^{3,4}$, TE-CHUN SHEN $^{3}$, \\ MENG-LIANG LIN $^{5}$, CHE-YI CHAO $^{6}$, YUN-CHI WANG $^{3}$, CHIA-WEN TSAI $^{3}$ and DA-TIAN BAU ${ }^{3,7,8}$ \\ ${ }^{1}$ Department of Clinical Laboratory, National Cancer Center/Cancer Hospital, \\ Chinese Academy of Medical Sciences and Peking Union Medical College, Beijing, P.R. China; \\ ${ }^{2}$ School of Post-baccalaureate Chinese Medicine, College of Chinese Medicine, \\ China Medical University, Taichung, Taiwan, R.O.C.; \\ ${ }^{3}$ Terry Fox Cancer Research Laboratory, Translational Medicine Research Center, \\ China Medical University Hospital, Taichung, Taiwan, R.O.C.; \\ ${ }^{4}$ Department of Otolaryngology, China Medical University Hospital, Taichung, Taiwan, R.O.C.; \\ ${ }^{5}$ Department of Medical Laboratory Science and Biotechnology, \\ China Medical University, Taichung, Taiwan, R.O.C.; \\ ${ }^{6}$ Department of Food Nutrition and Health Biotechnology, Asia University, Taichung, Taiwan, R.O.C.; \\ ${ }^{7}$ Graduate Institute of Biomedical Sciences, China Medical University, Taichung, Taiwan, R.O.C.; \\ ${ }^{8}$ Department of Bioinformatics and Medical Engineering, Asia University, Taichung, Taiwan, R.O.C.
}

\begin{abstract}
Background/Aim: Rs3824129 is a functional sixnucleotide insertion(I)/deletion $(D)$ polymorphism in the promoter region of caspase 8 , an essential apoptosis gene. We aimed to examine the association of this polymorphism with the risk of bladder cancer in the Taiwanese population. Materials and Methods: Caspase-8 rs3834129 genotypes were determined and their associations with bladder cancer risk were evaluated among 375 patients and 375 controls by the PCR-RFLP methodology. In addition, the interaction of caspase-8 rs3834129 genotypes with personal behaviors and clinicopathological features were examined. Results: The frequencies of II, ID and DD genotypes for caspase- 8 rs3834129 were non-differentially distributed between the two groups ( $p$ for trend=0.7187). Analysis of allelic frequency distribution also indicated that the $D$ variant allele was not associated with a risk of bladder cancer. There was no obvious joint interaction between caspase-8 rs3834129 genotypes and smoking, alcohol consumption, and clinical
\end{abstract}

\footnotetext{
*These Authors contributed equally to this study.

Correspondence to: Da-Tian Bau and Chia-Wen Tsai, Terry Fox Cancer Research Laboratory, Translational Medicine Research Center, China Medical University Hospital, 2 Yuh-Der Road, Taichung, 404 Taiwan, R.O.C. Tel: +886 422053366 (Ext. 5805), e-mail: datian@mail.cmuh.org.tw; artbau2@gmail.com
}

Key Words: Bladder cancer, case-control study, caspase-8, genotype, polymorphism. stage and grade. Conclusion: Caspase-8 rs3834129 genotypes play a minor role in the personal susceptibility to bladder cancer in Taiwan.

Bladder cancer is the sixth and seventeenth most commonly diagnosed cancer among men and women in the world, respectively, with nearly 500,000 newly diagnosed cases in 2018 (1). In Taiwan, the incidence of bladder cancer has been steadily increasing and currently occupy the ninth and fourteenth places among the common types of cancer for men and women, respectively (2). The high incidence has been suggested to be closely associated with a combinative effect of smoking, exposure to chemicals and PM2.5, prior radiation therapy, and frequent bladder infections, in addition to family history and genetic factors $(3,4)$. Interestingly, the contribution of genetic factors and the underlying etiology of bladder cancer remains largely unrevealed. In the past several years, although useful biomarkers for early detection of bladder cancer have been proposed (5-12), the practical genomic markers in clinics are still urgently needed and the mechanisms and signaling pathways warrant further investigations.

Apoptosis, also named as programmed cell death, is a process that removes unwanted cells from the body, with multiple cellular alterations including shrinkage of the cell, blebbing of the membrane, condensation of chromosome, and fragmentation of nucleus $(13,14)$. In the literature, mounting evidence has reported that the loss of homeostasis in the apoptosis program is associated with cancer initiation, progression, and treatment resistance $(14,15)$. 
A family of proteins known as caspases are the engines of apoptosis. There is mounting evidence linking the genetic variations in caspase genes with carcinogenesis. For instance, disruption of Apaf-1, mutation in caspase-10, and frameshift mutations in caspase-5 are closely associated with Noonan's Syndrome, autoimmune lymphoproliferative syndrome type II and hereditary gastrointestinal and endometrial tumors, respectively (16-18). The contribution of genetic variations of caspase-8, whose protein plays an important role in the extrinsic apoptosis pathway, to cancer susceptibility has also been examined in a few cancers (19-29), including neuroblastoma (22), lung cancer (23), breast cancer (24-26), prostate cancer $(27)$, colorectal cancer $(28,29)$, and oral cancer $(30,31)$.

One of the most commonly studied polymorphisms in caspase- 8 is rs3834129 $(-652,6 \mathrm{~N}$ ins/del), a six-nucleotide insertion/deletion polymorphism, which has been functionally characterized to lead to the under-expression of caspase-8 mRNA (21). As for bladder cancer, it was reported that caspase- $8 \mathrm{rs} 3834129 \mathrm{ins} / \mathrm{del}$ and del/del genotypes were statistically associated with lower bladder cancer risk in a Chinese population (32), but not in an Indian population (33). In 2017, a meta-analysis showed that caspase-8 rs3834129 polymorphism was associated with decreased risks for esophageal, lung, breast, gastric, colorectal, cervical, renal, and most of all, bladder cancers, and overall cancer in Asian populations (34). No study has evaluated this polymorphism in relation to bladder cancer susceptibility in Taiwan. Thus, in this study, we aimed at evaluating its association with bladder cancer risk, and examining the joint effects of caspase-8 rs3834129 genotype with smoking behaviors in a representative Taiwanese population.

\section{Materials and Methods}

Population sampling and recruiting. This multi-year study has been approved by the Institutional Review Board of the China Medical University Hospital (DMR104-IRB-158) and each participant has completed a written-informed consent. All the clinical investigations and records in this study were restrictively performed according to the principles expressed in the Declaration of Helsinki. To sum up, 375 patients diagnosed with bladder cancer were recruited at the China Medical University Hospital. After communication between patients and doctors, all the recruited cases voluntarily participated, completed a comprehensive questionnaire and provided 3 to $5 \mathrm{ml}$ of peripheral blood. The clinical characteristics of patients including histological details were abstracted from medical charts. Then, as a control, an equal number of non-cancer healthy subjects were selected by matching for age and gender after initial random sampling from the Health Examination Cohort visiting the hospital. They were asked in the same procedure as the cases. The exclusion criteria of the control group were defined as we published previously (5-10). Briefly, those with previous malignancy, metastasized cancer from another site or a tumor of unknown origin, and any familial or genetic diseases were excluded from the control group. As mentioned above, all participants completed a short questionnaire regarding personal characteristics, especially their individual habits. Smokers were defined as daily or almost daily smokers who had smoked at least five packs of cigarettes per year in their lifetime. Age of smoking initiation, whether they were currently smoking or had already quit, and if so, when they had quit, and on average, how many cigarettes they smoked or had smoked daily were recorded for smokers. Overall, the selective demographic characteristics of all the investigated subjects are summarized in Table I.

Genotyping procedures for caspase-8 rs3834129. The genomic DNA for each subject was extracted from his/her peripheral blood leukocytes using QIAamp Blood Mini Kit (Blossom, Taipei, Taiwan, ROC) accordingly, long-term stored at $-80^{\circ} \mathrm{C}, 100$-fold diluted and aliquoted in three Eppendorfs for caspase- 8 rs 3834129 genotyping as a working stock at $-20^{\circ} \mathrm{C}$, as described in our previous publications $(35,36)$. The caspase -8 rs 3834129 genotyping methodology as for the designing of the primer pairs and the selection of restriction enzyme are concisely described below. First, the polymerase chain reaction (PCR) program was set as: 1) one hot-start cycle at $94^{\circ} \mathrm{C}$ for $5 \mathrm{~min}$; 2) 35 repeated cycles of $94^{\circ} \mathrm{C}$ for $30 \mathrm{sec}, 59^{\circ} \mathrm{C}$ for $30 \mathrm{sec}$ and $72^{\circ} \mathrm{C}$ for $30 \mathrm{sec}$, and 3) a final extension at $72^{\circ} \mathrm{C}$ for $10 \mathrm{~min}$. Second, the oligo-nucleotide sequences of the forward and reverse primers for caspase- 8 rs3834129 genotyping were 5'-ACTCTGCATGCCAGGAGCTA-3' and 5'-CTGGGGAAG CCTCACTGTAT-3', respectively. Third, the PCR products were subject to full digestion with $P v u I I$ restriction enzyme (New England Biolabs, Beverly, MA, USA). Finally, the digested DNA products were subject to $3 \%$ agarose gel electrophoresis for $25 \mathrm{~min}$, staining in ethidium bromide and immediately observed under UVC irradiation. All the PCR-RFLP processing was repeated independently and blindly by at least two qualified researchers (Chang, Wang, Tsai, Tung or Li), and the genotyping analyzing results were $100 \%$ concordant among them.

Statistical methodology. The Student's $t$-test was used in age (a continuous variables) comparison between the two groups. The Pearson's chi-square was used in comparison for the distribution of the caspase- 8 rs3834129 genotypes among the subgroups according to the smoking status, etc. The associations between caspase- 8 rs3834129 genotypes and bladder cancer risk were estimated with individual odds ratios (ORs) plus 95\% confidence intervals (CIs). Any comparison results with a $p$-value less than 0.05 was identified as statistically significant.

\section{Results}

Comparison of characteristics between the bladder cancer patients and the healthy controls. The distributions of age, gender, smoking and drinking status in addition to clinical bladder cancer stages and grades for the 375 bladder cancer patients and 375 non-cancer controls are summarized in Table I. As mentioned in Materials and Methods, we have adopted the frequency matching strategy in our choosing of the healthy controls. Thus, there was no obvious difference in the aspects of age or gender between the case and control groups (Table I). As for personal behaviors, cigarette smokers and alcohol drinkers were at non-significant higher levels in the case group than in that of control (both $p>0.05$ ) 
Table I. Basic characteristics of the 375 patients with bladder cancer and 375 controls investigated in this study.

\begin{tabular}{|c|c|c|c|c|c|c|c|}
\hline \multirow[t]{2}{*}{ Characteristic } & \multicolumn{3}{|c|}{ Controls $(n=375)$} & \multicolumn{3}{|c|}{ Cases $(n=375)$} & \multirow[t]{2}{*}{$p$-Value } \\
\hline & $\mathrm{n}$ & $\%$ & Mean (SD) & $\mathrm{n}$ & $\%$ & Mean (SD) & \\
\hline Age (years) & & & $62.9(9.8)$ & & & $61.4(10.3)$ & $0.7315^{\mathrm{a}}$ \\
\hline Age group (years) & & & & & & & $0.7108^{b}$ \\
\hline$\leq 55$ & 152 & $40.5 \%$ & & 158 & $42.1 \%$ & & \\
\hline$>55$ & 223 & $59.5 \%$ & & 217 & $57.9 \%$ & & \\
\hline Gender & & & & & & & $0.5525^{\mathrm{b}}$ \\
\hline Male & 287 & $76.5 \%$ & & 279 & $74.4 \%$ & & \\
\hline Female & 88 & $23.5 \%$ & & 96 & $25.6 \%$ & & \\
\hline \multicolumn{8}{|l|}{ Personal habits } \\
\hline Cigarette smoking & 186 & $49.6 \%$ & & 201 & $53.6 \%$ & & $0.3063^{\mathrm{b}}$ \\
\hline Alcohol drinking & 176 & $46.9 \%$ & & 189 & $50.4 \%$ & & $0.3807^{b}$ \\
\hline \multicolumn{8}{|l|}{ Stage } \\
\hline Non-muscle-invasive & & & & 235 & $62.7 \%$ & & \\
\hline Muscle-invasive & & & & 140 & $37.3 \%$ & & \\
\hline \multicolumn{8}{|l|}{ Grade } \\
\hline Low & & & & 151 & $40.3 \%$ & & \\
\hline High & & & & 224 & $59.7 \%$ & & \\
\hline
\end{tabular}

SD: Standard deviation; abased on Student's $t$-test; bbased on Chi-square test.

Table II. Distributions of caspase-8 rs3834129 genotypic frequencies among bladder cancer patients and healthy controls.

\begin{tabular}{|c|c|c|c|c|}
\hline Genotype & Cases, n (\%) & Controls, n (\%) & Adjusted OR $(95 \% \mathrm{CI})^{\mathrm{a}}$ & $p$-Value ${ }^{\mathrm{b}}$ \\
\hline II & $216(57.6)$ & $205(54.7)$ & 1.00 (Reference) & \\
\hline ID & $137(36.5)$ & $146(38.9)$ & $0.89(0.71-1.13)$ & 0.4511 \\
\hline DD & $22(5.9)$ & $24(6.4)$ & $0.88(0.51-1.36)$ & 0.6539 \\
\hline ID+DD & $159(42.4)$ & $170(45.3)$ & $0.85(0.71-1.12)$ & 0.4183 \\
\hline$p_{\text {trend }}$ & & & & 0.7187 \\
\hline$p_{\mathrm{HWE}}$ & & & & 0.7690 \\
\hline
\end{tabular}

I: Insertion; D: deletion; OR: odds ratio; CI: confidence interval; HWE: Hardy-Weinberg Equilibrium; aData adjusted for confounding factors: age, gender, cigarette smoking and alcohol drinking status; bBased on chi-square test without Yates' correction.

(Table I, upper part). With regard to clinical features, $62.7 \%$ of the patients had non-muscle-invasive disease while $59.7 \%$ of the patients had high-grade tumors (Table I).

Association between caspase-8 promoter genotypes and bladder cancer risk. The comparisons about the distributions of caspase- 8 rs3834129 II, ID and DD genotypes among the cases and controls are presented in Table II. Overall, the genotypes of caspase- 8 rs3834129 were non-differentially distributed between the case and control groups ( $p$ for trend=0.7187) (Table II). In detail, heterozygous and homozygous variant ID and DD genotypes were not associated with altered bladder cancer risk compared with the wild-type II genotype (adjusted $\mathrm{OR}=0.89$ and 0.88 , $95 \% \mathrm{CI}=0.71-1.13$ and $0.51-1.36, p=0.4511$ and 0.6539 , respectively). In addition, in the dominant model, there was no association between caspase-8 rs3834129 ID+DD genotypes and bladder cancer risk, compared with the wildtype II genotype (adjusted $\mathrm{OR}=0.85,95 \% \mathrm{CI}=0.71-1.12$, $p=0.4183)$. The distribution of caspase -8 rs3834129 genotypes in the control group fits well with the HardyWeinberg Equilibrium $\left(p_{\mathrm{HWE}}=0.7690\right)$.

We have also performed the analysis of allelic frequency distributions for caspase- 8 rs3834129 using the methodology of chi-square test without Yates' correction, and the results are summarized in Table III. The results showed that caspase- 8 rs3834129 genotypes were not associated with the risk of bladder cancer. In detail, the relative percentage of variant allele D was $24.1 \%(n=181$ out of 750$)$ in the case group, slightly but non-significantly lower than that of $25.9 \%$ $(n=194$ out of 750$)$ in the control group (adjusted $\mathrm{OR}=0.89$, 95\% CI $=0.74-1.12, p=0.4382$ ) (Table III). 
Table III. Allelic frequencies for caspase-8 rs3834129 polymorphisms among the bladder cancer patients and healthy controls.

\begin{tabular}{lcccc}
\hline Allele & Cases, $\mathrm{n}(\%)(\mathrm{n}=750)$ & Controls, $\mathrm{n}(\%)(\mathrm{n}=750)$ & ${\text { Adjusted OR }(95 \% \mathrm{CI})^{\mathrm{a}}}$ & $p$-Value ${ }^{\mathrm{b}}$ \\
\hline $\mathrm{I}$ & $569(75.9)$ & $556(74.1)$ & 1.00 (Reference) & 0.4382 \\
$\mathrm{D}$ & $181(24.1)$ & $194(25.9)$ & $0.89(0.74-1.12)$ & \\
\hline
\end{tabular}

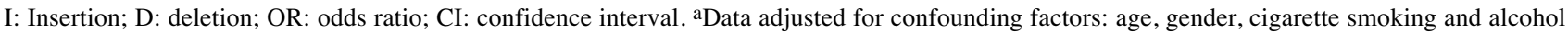
drinking status. bBased on chi-square test without Yates' correction.

Table IV. Odds ratios for association of caspase-8 rs3834129 genotype with bladder cancer after stratification by smoking status.

\begin{tabular}{|c|c|c|c|c|c|c|c|c|c|c|}
\hline \multirow[t]{2}{*}{ Genotype } & \multicolumn{2}{|c|}{ Non-smokers, $\mathrm{n}$} & \multirow[t]{2}{*}{ OR $(95 \% \mathrm{CI})^{\mathrm{a}}$} & \multirow[t]{2}{*}{$\mathrm{aOR}(95 \% \mathrm{CI})^{\mathrm{b}}$} & \multirow[t]{2}{*}{$p$-Value ${ }^{\mathrm{c}}$} & \multicolumn{2}{|c|}{ Smokers, $\mathrm{n}$} & \multirow[t]{2}{*}{ OR $(95 \% \mathrm{CI})^{\mathrm{a}}$} & \multirow[t]{2}{*}{$\mathrm{aOR}(95 \% \mathrm{CI})^{\mathrm{b}}$} & \multirow[t]{2}{*}{$p$-Value } \\
\hline & Controls & Cases & & & & Controls & Cases & & & \\
\hline II & 107 & 102 & 1.00 (ref) & 1.00 (ref) & & 98 & 114 & 1.00 (ref) & 1.00 (ref) & \\
\hline ID & 70 & 63 & $0.94(0.61-1.46)$ & $0.91(0.68-1.33)$ & 0.7057 & 76 & 74 & $0.84(0.55-1.27)$ & $0.89(0.62-1.38)$ & 0.4049 \\
\hline DD & 12 & 9 & $0.79(0.32-1.95)$ & $0.85(0.58-1.64)$ & 0.6032 & 12 & 13 & $0.93(0.41-2.14)$ & $0.88(0.59-1.33)$ & 0.8664 \\
\hline $\begin{array}{l}\text { Total } \\
\text { ptrend }\end{array}$ & 189 & 174 & & & 0.8619 & 186 & 201 & & & 0.7069 \\
\hline
\end{tabular}

aMultivariate logistic regression analysis; ${ }^{b}$ multivariate logistic regression analysis after adjusting for age, gender and alcohol drinking status; 'Chi-square without Yates' correction; insertion; D: deletion; CI: confidence interval; aOR: adjusted odds ratio.

Joint effects of caspase-8 rs3834129 genotypes and personal behavioral or clinical indexes on bladder cancer risk. We are interested in evaluating the joint effects of caspase-8 rs3834129 genotypes with personal behaviors such as cigarette smoking and alcohol drinking, and the results are shown in Tables IV. Firstly, among non-smokers, those carrying ID and DD genotypes at caspase-8 rs3834129 had 0.94- and 0.79-fold increased odds for bladder cancer risk $(95 \% \mathrm{CI}=0.61-1.46$ and $0.32-1.95, p=0.7057$ and 0.6032 ), respectively (Table IV, left panel). After adjusting for age, gender and alcohol drinking, the results remained non-significant for ID and DD genotypes (adjusted $\mathrm{OR}=0.91$ and $0.85,95 \% \mathrm{CI}=0.68-1.33$ and 0.58-1.64, respectively) (Table IV, left panel). Meanwhile, a nonsignificant effect was also found among smokers (Table IV, right panel). Secondly, among the subgroups of non-alcohol drinkers and alcohol drinkers, those carrying ID and DD genotypes at caspase- 8 rs3834129 had a non-significant differential risk of having bladder cancer (data not shown). Lastly, among the subgroups of different stages and grades, those carrying ID and DD genotypes at caspase- 8 rs3834129 did not have a significant differential risk of having bladder cancer either (data not shown).

\section{Discussion}

The cysteine-aspartic acid protease 8 is an evolutionarily conserved cysteine endoproteinase, named for its capacity to cleave peptide bonds after aspartic acid residues. It is responsible for initiating programmed cell death via activating caspase-3 in the apoptosis signaling cascade (37-39). Although down-regulation or loss of caspase- 8 have been frequently reported in various types of tumors, such as neuroblastoma (40, 41), medulloblastoma (42) and relapsing glioblastoma (43) and small cell lung carcinoma (44), the role of inherited genetic variations of caspase- 8 in cancer risk, progression and treatment responses are still debatable. Rs3834129 is the most commonly examined caspase- 8 variant. In 2007, Sun and his colleagues reported that the del allele at caspase- 8 rs3834129 was associated with a decreased susceptibility to multiple types of cancer, including esophageal, lung, breast, cervical, colorectal and gastric cancer (45). Subsequently, the genotypes of caspase- 8 rs3834129 were reported to be associated with the risk for brain tumor (22), breast cancer (27), melanoma (46) and kidney cancer (47). Biologically, the del genotype has been reported to destroy a stimulatory protein 1 binding element in the promoter regulatory region, leading to decreased caspase8 transcriptional activity and eventually suppression of $\mathrm{T}$ lymphocyte apoptosis (45). There were also some studies reporting no association between the genotypes of caspase- 8 rs3834129 with various types of cancer, for instance, the oral and colorectal cancers in the Taiwanese population $(31,48)$.

This is the first study evaluating caspase- 8 rs3834129 polymorphism in bladder cancer susceptibility in the Taiwanese population, however no significant association 
was found. Our results are consistent with a previous one performed in a South Indian population reporting that there was no significant association between caspase- 8 rs3834129 genotype and bladder cancer risk among a population containing 212 bladder cancer patients and 250 controls (33). However, it was reported that caspase- 8 rs3834129 del/del and del/ins genotypes were associated with a lower risk of bladder cancer risk in a Chinese population (32). The sample sizes of ours and Wang's study (32) are much similar, and both of the distributions of caspase- 8 rs3834129 fit the HWE well in the control groups. The distribution of caspase- 8 rs3834129 genotypes in the two control groups was not statistically different. The discrepant observation may come from different sampling methodologies or environment exposure, but not from differences in the genotyping methodology used or in the genetic background.

We also analyzed the possible joint interaction between caspase- 8 rs3834129 genotypes and several risk behaviors such as cigarette smoking and alcohol drinking. There was no interaction between caspase- 8 rs 3834129 genotypes and smoking or alcohol drinking on determining the personal risk to bladder cancer (Table IV). In 2009, Wang and his colleagues reported that there was a significant interaction between caspase- 8 rs3834129 genotypes and smoking on bladder cancer risk (32). The interaction of caspase- 8 rs3834129 genotypes and smoking on bladder cancer risk warrants further investigations. We have also examined the correlations between genotypes of caspase- 8 rs3834129 and clinicopathological features of the 375 bladder cancer patients. The results showed that there was no influence of caspase- 8 rs 3834129 on bladder cancer risk among patients of early or late stages, with either a low or higher grade.

To sum up, this study provided evidence that caspase- 8 rs3834129 was not associated with bladder cancer risk in this population of 375 cases and 375 controls. In addition, we found no altered risk among people with or without cigarette smoking or alcohol drinking. Moreover, caspase- 8 rs3834129 variant genotypes were not associated with clinical stage or grade. The contribution of caspase- 8 genotypes to bladder cancer needs to be studied in additional, ethnically diverse populations.

\section{Conflicts of Interest}

All the Authors declare no conflict of interest regarding this study.

\section{Authors' Contributions}

Research Design: Chen M, Tsai CW and Tsai YT; Patient and Questionnaire Summarize: Shih LC and Shen TC; Experiment Performance: Wang YC and Chang WS; Statistical Analysis: Tsai YT and Lin ML and Chao CY; Manuscript Writing: Chen M, Tsai CW and Bau DT; Reviewing and Revising: Bau DT, Chang WS and Tsai CW.

\section{Acknowledgements}

The Authors appreciate the Tissue-Bank of China Medical University Hospital for their excellent technical assistance and all the subjects, doctors (under the leadership of Prof. Hsi-Chin Wu), nurses and colleagues. The excellent techniques and efforts from Jyun-Peng Tung and Hsin-Ting Li are also appreciated. This study was supported mainly by China Medical University Hospital and Asia University (CMU108-ASIA-01) to Dr. Bau. The special statistical double-checking by Cheng-Li Lin supported with research grant from Taiwan Ministry of Health and Welfare Clinical Trial and Research Center of Excellence (MOHW108-TDU-B-212-133004) is also highly appreciated.

\section{References}

1 Bray F, Ferlay J, Soerjomataram I, Siegel RL, Torre LA and Jemal A: Global cancer statistics 2018: GLOBOCAN estimates of incidence and mortality worldwide for 36 cancers in 185 countries. CA Cancer J Clin 68: 394-424, 2018. PMID: 30207593. DOI: $10.3322 /$ caac. 21492

2 Taiwan Ministry of Health and Welfare Clinical Trial and Research Center of Excellence: Cancer Registration Annual Report. Available from: https://www.hpa.gov.tw/Pages/List. aspx ?nodeid $=269$ (last accessed on July 26th, 2019)

3 Yeh HL, Hsu SW, Chang YC, Chan TC, Tsou HC, Chang YC and Chiang PH: Spatial analysis of ambient PM2.5 exposure and bladder cancer mortality in Taiwan. Int J Environ Res Public Health 14: 508, 2017. PMID: 28489042. DOI: 10.3390/ijerph1 4050508

4 Chiu HF, Chen BK and Yang CY: Parity, age at first birth, and risk of death from bladder cancer: A population-based cohort study in Taiwan. Int J Environ Res Public Health 13: 1197, 2016. PMID: 27918463. DOI: 10.3390/ijerph13121197

5 Liao CH, Chang WS, Tsai CW, Hu PS, Wu HC, Hsu SW, Chen GL, Yueh TC, Shen TC, Hsia TC and Bau DT: Association of matrix metalloproteinase-7 genotypes with the risk of bladder cancer. In Vivo 32: 1045-1050, 2018. PMID: 30388078. DOI: 10.21873/invivo.11345

6 Tsai TH, Wang YM, Chang WS, Tsai CW, Wu HC, Hsu HM, Wang YC, Li HT, Gong CL, Bau DT and Li CY: Association of matrix metalloproteinase- 8 genotypes with the risk of bladder cancer. Anticancer Res 38: 5159-5164, 2018. PMID: 30194163. DOI: 10.21873 /anticanres.12838

7 Chang WS, Liao CH, Tsai CW, Hu PS, Wu HC, Hsu SW, Hsiao $\mathrm{CL}$, Hsu CH, Hung YW and Bau DT: Association of enhancer of zeste 2 (EZH2) genotypes with bladder cancer risk in Taiwan. Anticancer Res 36: 4509-4514, 2016. PMID: 27630289. DOI: 10.21873/anticanres.10997

8 Chang WS, Tsai CW, Ji HX, Wu HC, Chang YT, Lien CS, Liao WL, Shen WC, Tsai $\mathrm{CH}$ and Bau DT: Associations of cyclooxygenase 2 polymorphic genotypes with bladder cancer risk in Taiwan. Anticancer Res 33: 5401-5405, 2013. PMID: 24324075.

9 Bau DT, Chang CH, Tsai RY, Wang HC, Wang RF, Tsai CW, Yao $\mathrm{CH}$, Chen YS, Shyue SK and Huang CY: Significant association of caveolin-1 genotypes with bladder cancer susceptibility in Taiwan. Chin J Physiol 54: 153-160, 2011. PMID: 21789897.

10 Chang $\mathrm{CH}$, Chiu CF, Wang HC, Wu HC, Tsai RY, Tsai CW, Wang RF, Wang CH, Tsou YA and Bau DT: Significant association of ERCC6 single nucleotide polymorphisms with 
bladder cancer susceptibility in Taiwan. Anticancer Res 29: 5121-5124, 2009. PMID: 20044625.

11 Chang $\mathrm{CH}$, Wang RF, Tsai RY, Wu HC, Wang $\mathrm{CH}$, Tsai CW, Chang CL, Tsou YA, Liu CS and Bau DT: Significant association of XPD codon 312 single nucleotide polymorphism with bladder cancer susceptibility in Taiwan. Anticancer Res 29: 3903-3907, 2009. PMID: 19846926.

12 Chang $\mathrm{CH}$, Chang $\mathrm{CL}$, Tsai CW, Wu HC, Chiu CF, Wang RF, Liu CS, Lin CC and Bau DT: Significant association of an XRCC4 single nucleotide polymorphism with bladder cancer susceptibility in Taiwan. Anticancer Res 29: 1777-1782, 2009. PMID: 19443403.

13 Chen $M$ and Wang J: Initiator caspases in apoptosis signaling pathways. Apoptosis 7: 313-319, 2002. PMID: 12101390.

14 Lowe SW and Lin AW: Apoptosis in cancer. Carcinogenesis 21: 485-495, 2000. PMID: 10688869. DOI: 10.1093/carcin/21.3.485

15 Wang LH, Ting SC, Chen CH, Tsai CC, Lung O, Liu TC, Lee CW, Wang YY, Tsai CL and Lin YC: Polymorphisms in the apoptosis-associated genes FAS and FASL and risk of oral cancer and malignant potential of oral premalignant lesions in a Taiwanese population. J Oral Pathol Med 39: 155-161, 2010. PMID: 20359312. DOI: 10.1111/j.1600-0714.2009.00873.x

16 Cecconi F, Alvarez-Bolado G, Meyer BI, Roth KA and Gruss P: Apaf1 (CED-4 homolog) regulates programmed cell death in mammalian development. Cell 94: 727-737, 1998. PMID: 9753320. DOI: 10.1016/s0092-8674(00)81732-8

17 Wang J, Zheng L, Lobito A, Chan FK, Dale J, Sneller M, Yao X, Puck JM, Straus SE and Lenardo MJ: Inherited human Caspase 10 mutations underlie defective lymphocyte and dendritic cell apoptosis in autoimmune lymphoproliferative syndrome type II. Cell 98: 47-58, 1999. PMID: 10412980. DOI: 10.1016/S0092-8674(00)80605-4

18 Schwartz S, Jr., Yamamoto H, Navarro M, Maestro M, Reventos $\mathrm{J}$ and Perucho $\mathrm{M}$ : Frameshift mutations at mononucleotide repeats in caspase-5 and other target genes in endometrial and gastrointestinal cancer of the microsatellite mutator phenotype. Cancer Res 59: 2995-3002, 1999. PMID: 10383166.

19 Kuwana T, Smith JJ, Muzio M, Dixit V, Newmeyer DD and Kornbluth S: Apoptosis induction by caspase- 8 is amplified through the mitochondrial release of cytochrome c. J Biol Chem 273: 16589-16594, 1998. PMID: 9632731. DOI: 10.1074/jbc. 273.26.16589

20 Yu J, Zhang L, Hwang PM, Kinzler KW and Vogelstein B: PUMA induces the rapid apoptosis of colorectal cancer cells. Mol Cell 7: 673-682, 2001. PMID: 11463391.

21 Hashemi M, Eskandari-Nasab E, Fazaeli A, Rezaei H, Mashhadi MA, Arbabi F and Taheri M: Bi-directional PCR allele-specific amplification (bi-PASA) for detection of caspase-8 $-6526 \mathrm{~N}$ ins/del promoter polymorphism (rs3834129) in breast cancer. Gene 505: 176-179, 2012. PMID: 22659694. DOI: 10.1016/ j.gene.2012.05.043

22 Rihani A, De Wilde B, Zeka F, Laureys G, Francotte N, Tonini GP, Coco S, Versteeg R, Noguera R, Schulte JH, Eggert A, Stallings RL, Speleman F, Vandesompele J and Van Maerken T: CASP8 SNP D302H (rs1045485) is associated with worse survival in MYCN-amplified neuroblastoma patients. PLoS One 9: e114696, 2014. PMID: 25502557. DOI: 10.1371/journal. pone.0114696

23 Son JW, Kang HK, Chae MH, Choi JE, Park JM, Lee WK, Kim CH, Kim DS, Kam S, Kang YM and Park JY: Polymorphisms in the caspase- 8 gene and the risk of lung cancer. Cancer Genet Cytogenet 169: 121-127, 2006. PMID: 16938569. DOI: 10.1016/ j.cancergencyto.2006.04.001

24 Kuhlmann JD, Bankfalvi A, Schmid KW, Callies R, Kimmig R, Wimberger P, Siffert W and Bachmann HS: Prognostic relevance of caspase $8-6526 \mathrm{~N}$ InsDel and Asp302His polymorphisms for breast cancer. BMC Cancer 16: 618, 2016. PMID: 27507139. DOI: $10.1186 / \mathrm{s} 12885-016-2662-\mathrm{x}$

25 Park HL, Ziogas A, Chang J, Desai B, Bessonova L, Garner C, Lee E, Neuhausen SL, Wang SS, Ma H, Clague J, Reynolds P, Lacey JV, Jr., Bernstein L and Anton-Culver H: Novel polymorphisms in caspase- 8 are associated with breast cancer risk in the California Teachers Study. BMC Cancer 16: 14, 2016. PMID: 26758508. DOI: 10.1186/s12885-015-2036-9

26 Zhang Y, Li W, Hong Y, Wu G, He K and Liu D: A systematic analysis of the association studies between CASP8 D302H polymorphisms and breast cancer risk. J Genet 96: 283-289, 2017. PMID: 28674227.

27 Zhang CD, Li HT, Liu K, Lin ZD, Peng QL, Qin X, He M, Wu $\mathrm{H}, \mathrm{Mo} \mathrm{ZN}$ and Yang XL: Impact of caspase-8 (CASP8) -652 6N del and D302H polymorphisms on prostate cancer in different ethnic groups. Asian Pac J Cancer Prev 15: 7713-7718, 2014. PMID: 25292051. DOI: 10.7314/apjcp.2014.15.18.7713

$28 \mathrm{Du}$ H, Song GX, Fang MZ, Shu YQ, Zhao X and Zhu LJ: A meta-analysis of caspase-8 $-6526 \mathrm{~N}$ del polymorphism and digestive tract cancer risk. J Biomed Res 33: 173-180, 2019. PMID: 30057371. DOI: 10.7555/JBR.32.20160030

29 Wu Z, Li Y, Li S, Zhu L, Li G, Yu Z, Zhao X, Ge J, Cui B, Dong $\mathrm{X}$, Tian S, Hu F and Zhao Y: Association between main Caspase gene polymorphisms and the susceptibility and prognosis of colorectal cancer. Med Oncol 30: 565, 2013. PMID: 23715747. DOI: $10.1007 / \mathrm{s} 12032-013-0565-0$

30 Arunkumar G, Murugan AK, Nagarajan M, Ajay C, Rajaraman $\mathrm{R}$ and Munirajan AK: Absence of the frequently reported PIK3CA, CASP8, and NOTCH1 mutations in South Indian oral cancers. Oral Dis 23: 669-673, 2017. PMID: 28181739. DOI: 10.1111/odi.12655

31 Shih LC, Tsai CW, Sun KT, Hsu HM, Shen TC, Tsai YT, Chang WS, Lin ML, Wang YC, Gong CL and Bau DT: Association of caspase-8 genotypes with oral cancer risk in Taiwan. In Vivo 33: 1151-1156, 2019. PMID: 31280204. DOI: 10.21873/invivo. 11585

32 Wang M, Zhang Z, Tian Y, Shao J and Zhang Z: A six-nucleotide insertion-deletion polymorphism in the CASP8 promoter associated with risk and progression of bladder cancer. Clin Cancer Res 15: 2567-2572, 2009. PMID: 19276244. DOI: 10.1158/1078-0432.CCR-08-2829

33 Gangwar R, Mandhani A and Mittal RD: Caspase 9 and caspase 8 gene polymorphisms and susceptibility to bladder cancer in north Indian population. Ann Surg Oncol 16: 2028-2034, 2009. PMID: 19412632. DOI: 10.1245/s10434-009-0488-3

34 Cai J, Ye Q, Luo S, Zhuang Z, He K, Zhuo ZJ, Wan X and Cheng J: CASP8 -652 6N insertion/deletion polymorphism and overall cancer risk: evidence from 49 studies. Oncotarget 8 : 56780-56790, 2017. PMID: 28915630. DOI: 10.18632/ oncotarget.18187

35 Lin KM, Yang MD, Tsai CW, Chang WS, Hsiao CL, Jeng LB, Yueh TC, Lee MC and Bau DT: The role of MTHFR genotype in colorectal cancer susceptibility in Taiwan. Anticancer Res 38: 2001-2006, 2018. PMID: 29599316. DOI: 10.21873/anticanres. 12438 
36 Shih LC, Li CH, Sun KT, Chen LY, Hsu CL, Hung YW, Wu CN Hsia TC, Shen TC, Chang WS, Shih TC, Tsai CW and Bau DT: Association of matrix metalloproteinase-7 genotypes to the risk of oral cancer in Taiwan. Anticancer Res 38: 2087-2092, 2018 PMID: 29599326. DOI: 10.21873/anticanres.12448

37 Kruidering $M$ and Evan GI: Caspase- 8 in apoptosis: the beginning of "the end"? IUBMB Life 50: 85-90, 2000. PMID: 1118596. DOI: $10.1080 / 713803693$

38 Ghavami S, Hashemi M, Ande SR, Yeganeh B, Xiao W, Eshraghi M, Bus CJ, Kadkhoda K, Wiechec E, Halayko AJ and Los M: Apoptosis and cancer: mutations within caspase genes. J Med Genet 46: 497-510, 2009. PMID: 19505876. DOI: 10.1136/jmg.2009.066944

$39 \mathrm{Li} \mathrm{J}$ and Yuan J: Caspases in apoptosis and beyond. Oncogene 27: 6194-6206, 2008. PMID: 18931687. DOI: 10.1038/onc.2008. 297

40 Hopkins-Donaldson S, Bodmer JL, Bourloud KB, Brognara CB, Tschopp J and Gross N: Loss of caspase-8 expression in highly malignant human neuroblastoma cells correlates with resistance to tumor necrosis factor-related apoptosis-inducing ligand-induced apoptosis. Cancer Res 60: 4315-4319, 2000. PMID: 10969767.

41 Teitz T, Lahti JM and Kidd VJ: Aggressive childhood neuroblastomas do not express caspase-8: an important component of programmed cell death. J Mol Med (Berl) 79: 428-436, 2001 PMID: 11511973.

42 Ebinger M, Senf L, Wachowski O and Scheurlen W: Promoter methylation pattern of caspase-8, P16INK4A, MGMT, TIMP-3, and E-cadherin in medulloblastoma. Pathol Oncol Res 10: 1721, 2004. PMID: 15029256. DOI: PAOR.2004.10.1.0017

43 Martinez R, Setien F, Voelter C, Casado S, Quesada MP, Schackert $\mathrm{G}$ and Esteller M: CpG island promoter hypermethylation of the pro-apoptotic gene caspase- 8 is a common hallmark of relapsed glioblastoma multiforme. Carcinogenesis 28: 1264-1268, 2007. PMID: 17272309. DOI: 10.1093/carcin/bgm014
44 Shivapurkar N, Toyooka S, Eby MT, Huang CX, Sathyanarayana UG, Cunningham HT, Reddy JL, Brambilla E, Takahashi T, Minna JD, Chaudhary PM and Gazdar AF: Differential inactivation of caspase-8 in lung cancers. Cancer Biol Ther 1 : 65-69, 2002. PMID: 12170765. DOI: 10.4161/cbt.1.1.45

45 Sun T, Gao Y, Tan W, Ma S, Shi Y, Yao J, Guo Y, Yang M, Zhang $\mathrm{X}$, Zhang $\mathrm{Q}$, Zeng $\mathrm{C}$ and Lin D: A six-nucleotide insertion-deletion polymorphism in the CASP8 promoter is associated with susceptibility to multiple cancers. Nat Genet 39 : 605-613, 2007. PMID: 17450141. DOI: $10.1038 / \mathrm{ng} 2030$

$46 \mathrm{Li} \mathrm{C}$, Zhao H, Hu Z, Liu Z, Wang LE, Gershenwald JE, Prieto VG, Lee JE, Duvic M, Grimm EA and Wei Q: Genetic variants and haplotypes of the caspase- 8 and caspase- 10 genes contribute to susceptibility to cutaneous melanoma. Hum Mutat 29: 14431451, 2008. PMID: 18563783. DOI: 10.1002/humu.20803

47 de Martino M, Haitel A, Schatzl G, Klingler HC and Klatte T: The CASP8 $-6526 \mathrm{~N}$ insertion/deletion promoter polymorphism is associated with renal cell carcinoma risk and metastasis. J Urol 190: 717-722, 2013. PMID: 23313206. DOI: 10.1016/ j.juro.2013.01.008

$48 \mathrm{Wu}$ MH, Hung YW, Gong CL, Chao CC, Yueh TC, Wang SC, Lai YL, Hsu SW, Fu CK, Wang YC, Ke TW, Chang WS, Tsai $\mathrm{CW}$ and Bau DT: Contribution of caspase-8 genotypes to colorectal cancer risk in Taiwan. Anticancer Res 39: 2791-2797, 2019. PMID: 31177115 . DOI: 10.21873/anticanres.13406
Received July 19, 2019

Revised July 25, 2019

Accepted July 26, 2019 